\title{
Cleaner industrial processes using hydrogen peroxide $^{*}$
}

\author{
William R. Sanderson \\ Consultant to Solvay SA, c/o Solvay Interox Ltd., P.O. Box 7, Baronet Works, \\ Warrington WA4 6HB, UK
}

\begin{abstract}
Recent research progress in catalytic systems for potential use with hydrogen peroxide in industrial chemical synthesis is reviewed, with special focus on work published in the last five years. The main types of chemistry employed are critically appraised regarding their suitability for industrial exploitation. The most significant catalyst types are discussed in terms of the positive features identified to date, and the obstacles yet to be surmounted in order to become more widely adopted. It is believed that fully inorganic systems have more scope for commercialization than those containing organic ligands or supports, however robust. Critical targets are larger-pore analogs of titanium silicalite TS-1, more exploration of smectitebased materials, effective immobilization of activated metal peroxo systems, and improvements in design and manipulation of polyoxometallate compounds. Cooperation between branches of chemistry that have not traditionally worked closely together is advocated.
\end{abstract}

\section{INTRODUCTION}

This article is concerned with sustainable chemistry, and adheres to the objective green chemistry definitions already published [1], and discussed elsewhere in this issue.

There have, overall, been two related trends, from a factory-based approach to a plant-based approach, and from waste management ("cure") to waste avoidance ("prevention"). One should not rush to denigrate the traditional "end-of-pipe" method of managing waste at the factory level, since many mature chemical sites do this very effectively, even in today's stringent operating environment. Rather, the message is that design of new processes and plants can benefit by following, as far as possible, the principles of "atom utilization" or "atom economy" [2], to eliminate waste at source.

By any criteria, hydrogen peroxide has already made an appreciable contribution to a cleaner chemical industry. Its inherent chemistry as an oxidant [3] continues to give it a role beyond that of oxygen, especially in selective oxidations. As the world's leading producer, Solvay has played its part in discovering the technology to maintain and accelerate this development (see box on next page). This paper seeks to review progress, particularly in catalytic oxidation methods for chemical synthesis based on $\mathrm{H}_{2} \mathrm{O}_{2}$, analyzing the strengths, weaknesses, and current challenges in this area. Such a task is not easy for at least two reasons: firstly, there is a huge volume of work to be surveyed in a small space [4]; and secondly, many of the academic studies do not reveal the full potential of the catalysts identified, since experiments are not extended to high turnover (a critical parameter for industrial exploitation). Hence, there is inevitably an element of personal opinion in this review, for which the reader's understanding is asked.

\section{GENERAL ISSUES AND CHALLENGES}

As indicated above, there are difficulties in comparing and appraising the commercial potential of published work on peroxygen oxidations. In journals, the screening approach adopted at the research

*Pure Appl. Chem. Vol. 72, No. 7, 2000. A special topic issue on green chemistry. 


\section{Solvay's efforts towards clean catalytic processes}

Over the last 15 years or so, Solvay (via the Interox joint venture before 1992) has, in addition to very significant in-house $R \& D$ effort, supported a host of projects at research institutions throughout Western Europe and the United States. Below is a non-exhaustive list of collaborations, aimed either at the discovery of new oxidation technology using hydrogen peroxide and its derivatives, or at mechanistic studies underpinning such advances. The author of this paper was personally involved in over $90 \%$ of this work, and owes his own understanding of the subject in large measure to those named here.

\begin{tabular}{|c|c|c|c|c|}
\hline Institution (UK) & Key Collaborators & Institution & Country & Key Collaborators \\
\hline Imperial College & $\begin{array}{l}\text { Prof W. P. Griffith } \\
\text { Prof M. G. Spiro }\end{array}$ & TU Delft & Netherlands & $\begin{array}{l}\text { Prof H. van Bekkum } \\
\text { Prof R. A. Sheldon }\end{array}$ \\
\hline $\begin{array}{l}\text { University of East } \\
\text { Anglia }\end{array}$ & $\begin{array}{l}\text { Prof A. McKillop } \\
\text { Dr R. D. Cannon } \\
\text { Dr U. A. Jayasooriya }\end{array}$ & $\begin{array}{l}\text { TNO Utrecht/ } \\
\text { Zeist }\end{array}$ & Netherlands & $\begin{array}{l}\text { Dr H. A. Meinema } \\
\text { Dr J. Terheijden }\end{array}$ \\
\hline University of York & $\begin{array}{l}\text { Prof B. C. Gilbert } \\
\text { Prof J. H. Clark } \\
\text { Dr J. R. Lindsay Smith } \\
\text { Dr C. B. Thomas } \\
\text { Dr B. J. Keely }\end{array}$ & $\begin{array}{l}\text { Ecole } \\
\text { Polytechnique }\end{array}$ & France & $\begin{array}{l}\text { Dr J. Fossey } \\
\text { Dr D. Lefort }\end{array}$ \\
\hline Liverpool University & $\begin{array}{l}\text { Prof R. A. W. Johnstone } \\
\text { Dr A. J. Carnell }\end{array}$ & $\begin{array}{l}\text { Université René } \\
\text { Descartes }\end{array}$ & France & $\begin{array}{l}\text { Dr D. Mansuy } \\
\text { Dr P. Battioni }\end{array}$ \\
\hline Leeds University & $\begin{array}{l}\text { Prof A. A. Clifford } \\
\text { Dr C. M. Rayner }\end{array}$ & $\begin{array}{l}\text { Universiteit } \\
\text { Tübingen }\end{array}$ & Germany & $\begin{array}{l}\text { Prof E. Bayer } \\
\text { Prof Hanack }\end{array}$ \\
\hline $\begin{array}{l}\text { Loughborough } \\
\text { University }\end{array}$ & Prof H. Heaney & $\begin{array}{l}\text { Universiteit } \\
\text { Aachen }\end{array}$ & Germany & Prof S. Warwel \\
\hline Oxford University & $\begin{array}{l}\text { Prof R. J. P. Williams } \\
\text { Prof J. M. Brown }\end{array}$ & $\begin{array}{l}\text { University of } \\
\text { Padua }\end{array}$ & Italy & $\begin{array}{l}\text { Prof G. Modena } \\
\text { Prof F. DiFuria }\end{array}$ \\
\hline Coventry University & $\begin{array}{l}\text { Prof T. J. Mason } \\
\text { Dr P. H. Lorimer }\end{array}$ & $\begin{array}{l}\text { Coimbra } \\
\text { University }\end{array}$ & Portugal & $\begin{array}{l}\text { Prof A. Rocha } \\
\text { Gonsalves }\end{array}$ \\
\hline & & $\begin{array}{l}\text { Princeton } \\
\text { University } \\
\text { Brown University } \\
\text { Emory University }\end{array}$ & $\begin{array}{l}\text { USA } \\
\text { USA } \\
\text { USA }\end{array}$ & $\begin{array}{l}\text { Prof J. T. Groves } \\
\text { Prof J. O. Edwards } \\
\text { Prof C. L. Hill }\end{array}$ \\
\hline
\end{tabular}

stage gives results that typically fall far short of demonstrating industrial feasibility, since "friendly" conditions are used. For example, apart from the lack of information on turnover limits, it is quite common to find work done at high excess of substrate to peroxide (say, 5:1 molar or greater) which in liquid-phase oxidations is a serious drawback. Others have referred to the lack of suitable blank experiments in many cases, and to insufficient product analysis and recycle data to prove that the active catalyst remains within the material added [5]. In patents, the intention is often to maximize coverage 
without disclosing all details of the best embodiments, again making interpretation and evaluation difficult. One sees many claims to cover a range of peroxygen oxidants when there is no evidence in the examples that they were even tried.

The choice of substrate is a special concern. Two common test reactions for electrophilic peroxygen systems are epoxidation and (organic) sulphide oxidation. In the former case, lots of results are reported for cyclooctene, which is not only about the easiest common olefin to epoxidize, but also forms epoxides readily with dioxygen and other oxidants which do not usually transfer single oxygen atoms. Industrial demand, on the other hand, is most often for epoxidation of substrates at the very far end of the reactivity series [6] - terminal olefins and allylic compounds-and no conclusions can be drawn from cyclooctene results. Similarly, thioanisole (PhSMe) is a common test substrate for catalyzed peroxygen oxidation at sulfur, but the uncatalyzed reaction is quite significant, and again under some conditions dioxygen also oxidizes the sulfur.

After a long period when catalysis was essentially the province of heavy chemical production, it is now increasingly relevant to fine chemical manufacture, often for pharmaceutical/ veterinary or agrochemical use. Such products need to be rigorously free from toxic metals, down to ppm or even ppb levels. This has implications for catalyst recovery and leach levels, which may be especially difficult to achieve for "immobilized" (heterogenized) homogeneous catalysts. This favors covalent over ionic binding, or physical confinement of dissociable complexes.

A perennial challenge in $\mathrm{H}_{2} \mathrm{O}_{2}$ oxidations is its strongly hydrophilic nature, and the mismatch between this and the hydrophobic character of most substrates. The use of "bridging" solvents such as acetonitrile, t-butanol and methanol is a partial answer, as is phase-transfer catalysis using two-phase polar/non-polar mixtures. In academic studies, chlorinated solvents are still commonly used as the organic component, whereas this is often not feasible in new industrial processes: alternatives such as toluene are employed, which may need different phase-transfer catalysts.

The difficulty of "mixed polarity" is magnified in heterogeneous systems, where surface affinity for all reactants must be provided such that effective local concentrations are maintained. This factor seems often to be overlooked, there being an implicit assumption that bulk concentrations of reactants will be similar to those near the active site; good catalysts may be missed by neglecting this influence.

Finally, again related to hydrophilic conditions, the reducing properties of $\mathrm{H}_{2} \mathrm{O}_{2}$ are often more evident in the presence of water, favoring decomposition and nonselective reactions in the presence of catalysts that perform well in organic media. Unfortunately, owing to safety constraints, and the simple fact that water is usually a co-product of reactions, the large-scale industrial use of organic $\mathrm{H}_{2} \mathrm{O}_{2}$ solutions is not often attractive. This could change somewhat in the future, in the light of chemical engineering developments such as reactive distillation.

\section{CATALYST TYPES}

In the remainder of this review the chief catalyst types will be discussed, in terms of the positive features identified to date, and the obstacles yet to be surmounted in order to become more widely exploited.

\section{Redox metal complexes}

Most work in this area has been done with iron and manganese porphyrins [7], aimed largely at oxygen transfer to form $\mathrm{M}^{(\mathrm{n}+2)+}=\mathrm{O}$ oxene intermediates. These were not thought at all relevant as commercial catalysts until relatively recently, when the relative robustness of $\mathrm{Mn}$ (III) tetrakis(meso2,6-dichlorophenyl) porphyrin (MnTDCPP) was found, along with high-yielding preparative methods. Whenever organic ligands are present in oxidation catalysts, some degradation over long time periods almost invariably occurs. However, in the case of porphyrins, this has been mitigated by electronwithdrawing meso-substituents such as are present in TDCPP, and in later generations by $\beta$-substitution also [8]. Nature does not do this, instead providing steric shielding of the meso-positions, along with

(C) 2000 IUPAC, Pure and Applied Chemistry 72, 1289-1304 
"site isolation". On the other hand, metalloporphyrins in solution can be degraded by intermolecular "face to edge" contact between oxene and ligand. Furthermore, with $\mathrm{H}_{2} \mathrm{O}_{2}$ as the oxidant a further problem can arise- that of homolytic rather than heterolytic cleavage of the $\mathrm{M}-\mathrm{O}-$ $\mathrm{O}-\mathrm{H}$ intermediate. This will generate free hydroxyl radical, an indiscriminate oxidant that will attack even the most unreactive ligands. That is why $\mathrm{H}_{2} \mathrm{O}_{2}$ is often found to be more aggressive to porphyrins than hypochlorite, even though the latter is a more powerful oxidant per

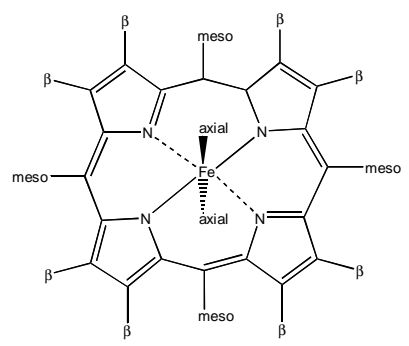
$s e$. Related to this, the electron-withdrawing substituents used to stabilize porphyrins (and to make the oxene a more powerful electrophile) also make heterolytic cleavage less favorable, hence actually encouraging formation of oxidizing radicals. Such systems can no longer really be called "biomimetic". Some features of iron and manganese systems now need to be discussed separately.

Manganese porphyrins mainly depend on a co-catalyst to assist heterolytic-O-O- cleavage, by donating electrons as an axial ligand below the porphyrin plane, and by assisting in proton transfer to the $-\mathrm{OH}$ to create $-\mathrm{O}^{+} \mathrm{H}_{2}$ as leaving group. Imidazoles are the traditional choice, reflecting the role of histidine in natural peroxidases. However, in "free" systems, these are rapidly degraded. Alternatives such as ammonium acetate and aliphatic amine $N$-oxides appear more practicable. MnTDCPP oxidizes terminal n-olefins such as non-1-ene with high turnover and little loss of catalyst-in fact, catalyst doses are so small as to make disposal after a single batch reaction potentially economic for fine chemicals. There is always, however, some competition between substrate oxidation and catalyst degradation, which is more serious for less reactive substrates, and masked in much literature work by the use of large excesses of substrate to $\mathrm{H}_{2} \mathrm{O}_{2}$. In very electron-deficient Mn porphyrins (such as poly- $\beta$-nitro [9], or poly- $\beta$-chloro [10]), the role of the axial ligand is diminished, and it may be that the $\mathrm{M}-\mathrm{O}-\mathrm{O}-\mathrm{H}$ species acts directly on the substrate, as has been shown for similar iron systems. The catalytic potential of such systems remains to be established.

In the case of iron, imidazole is not very useful in homogeneous systems, since the inactive transdicoordinated complex is readily formed. Accordingly, homolytic-O-O- cleavage is more of a factor. Moreover, it appears that when oxygen transfer from the oxene does occur, it is in two discrete 1-electron steps, as shown, for example, by isomerization of cis-stilbene to the trans-epoxide, and by the greater tendency to hydroxylate aryl-substituted olefins along with the epoxidation. This is likely to be due to the absence of $\mathrm{Fe}^{\mathrm{V}}$ in the resonance equilibria:

$$
\begin{aligned}
& \mathrm{p}^{+} \mathrm{Fe}^{\mathrm{IV}}=\mathrm{O} \leftrightarrow \mathrm{pFe}^{\mathrm{IV}}-\mathrm{O} \leftrightarrow \mathrm{p}^{+} \cdot \mathrm{Fe}^{\mathrm{III}}-\mathrm{O} \\
& \left(\text { cf } \mathrm{pMn}^{\mathrm{V}}=\mathrm{O} \leftrightarrow \mathrm{p}^{+} \cdot \mathrm{Mn}^{\mathrm{IV}}=\mathrm{O} \leftrightarrow \mathrm{pMn}^{\mathrm{IV}}-\mathrm{O}\right. \text { ) }
\end{aligned}
$$

allowing significant radical character arising from the single-bonded species. Recent mechanistic work has also shown, however, that -O-O- cleavage is not necessary to obtain a catalytic system-the $\mathrm{Fe}-\mathrm{O}-\mathrm{O}-\mathrm{H}$ intermediate can transfer oxygen directly to substrates [11]. Where the oxene is formed, $\mathrm{Fe}$ porphyrins have been shown to exhibit "oxo-hydroxo tautomerism" in the presence of water, which is a favored axial ligand. All in all, iron porphyrins may have the same catalytic potential as manganese, with less dependence on cocatalysts, but fewer studies on relevant substrates have been reported.

Water-soluble Mn [13] and Fe [14] porphyrins have been prepared, mainly by substitution of meso-phenyl substituents with charged groups such as quaternary ammonium or sulphonate.

Attempts to immobilize porphyrins on solid supports [15], whether by physical or chemical attachment, have met with limited success to date. While site isolation should improve catalyst life by preventing face-to-edge contact, this is counterbalanced by the loss of activity usually seen. A likely major factor is lack of control over the relative surface affinity for reactants (and products). In Mn systems, co-catalyst access is also often needed - tethering of the co-factor is not a promising approach owing to its own degradation, and to the dual role of axial ligand and proton donor required (though these functions can be performed by different molecules).

(C) 2000 IUPAC, Pure and Applied Chemistry 72, 1289-1304 
Ruthenium porphyrins cannot be used directly as catalysts with $\mathrm{H}_{2} \mathrm{O}_{2}$, but the latter can be used to generate $\mathrm{N}$-oxides which are effective $\mathrm{O}$-donors to $\mathrm{Ru}$ in these complexes. In such a way, $\mathrm{Ru}^{\mathrm{IV}-\mathrm{VI}}$ redox chemistry can be accessed, again involving oxenes. This is very slow, however. There is a prospect of a faster $\mathrm{Ru}^{\mathrm{III}-\mathrm{V}}$ couple [16] which has yet to be explored.

Recent work with phthalocyanines [17] has revealed new catalytic poten-

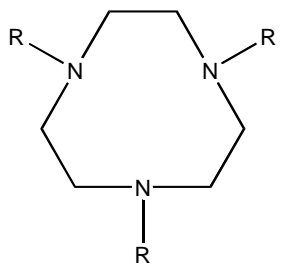
tial, a key advantage being their cheap and simple preparation, incorporating metals from all three rows of the periodic table. They can be readily prepared in zeolite cavities and on other supports [18]. They appear, however, to be more suited to $\mathrm{C}-\mathrm{H}$ oxidation reactions than to epoxidation.

Another relative newcomer as a ligand is sym-triazacyclononane (tacn) and its N,N',N"-trimethyl analog (tmtacn). These form stable complexes with all first-row transition metals, and the manganese complexes in particular offer electrophilic oxygen-transfer catalysis with $\mathrm{H}_{2} \mathrm{O}_{2}$ [19], and radical hydroxylation of saturated hydrocarbons in acetic acid solution [82]. Once again, ligand degradation is not negligible over long periods, and leads to a loss of selectivity as $\mathrm{Mn}$ is liberated in different forms. The consequences of this for catalysis of stain bleaching in domestic laundry are well known. Salen (Schiff-base type) ligands are another class which have not achieved much success with $\mathrm{H}_{2} \mathrm{O}_{2}$ owing to their easy oxidizability.

By contrast, hypervalent metal complexes with tetragonal amide ligands are much more robust to oxidation, and recent reports suggest significant potential of iron amide complexes [20] as catalysts for $\mathrm{H}_{2} \mathrm{O}_{2}$ oxidations.

Hydrogen peroxide can be used as an oxidant in aromatic side-chain oxidations in acetic acid, catalyzed by cobalt and bromide salts [21] with or without manganese, or with cerium and bromide [22]. The first of these systems is analogous to dioxygen oxidations carried out at high pressure on

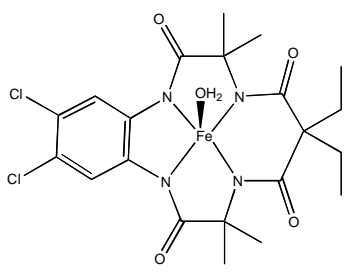
very large scale, to make terephthalic and isophthalic acids from the corresponding xylenes. The ability to use ambient pressure in general purpose plant, with $\mathrm{H}_{2} \mathrm{O}_{2}$ as oxidant, is useful for fine chemicals. In this case, the second oxidation on a side chain is faster than the first, tending to give toluic acid or aldehyde intermediates if a low excess of oxidant is used. Another sidechain oxidation system uses hydrogen peroxide and hydrogen bromide irradiated with visible light [23], the active species being atomic bromine. Here, the second oxidation is slower than the first, offering a selective route to dialcohols from xylenes, for example.

There have been several attempts at encapsulation [24] of some of the above types of complex [and others such as $\mathrm{Mn}(\mathrm{bpy})_{3}$ ]: in zeolite cavities (e.g., zeolite Y) [25]; smectite interlayers (e.g., montmorillonite, layered double hydroxide) [26]; mesopore channels (e.g., MCM-41) [27]; amorphous silica [28]; or membranes (e.g., polydimethylsiloxane) [29]—using many synthetic approaches. So far, moderately good catalysts have resulted in a few cases. Transport of reactants and products within the support, and space around the active site, are common limitations for "ship in a bottle" catalysts [86], which are more difficult to solve than for framework-substituted catalysts. Only quite low loadings can be tolerated, to ensure adequate mobility. Smectites have the option of pillaring to increase interlayer volume, and are underexplored, maybe because many more catalysis groups specialize in zeolite/ mesopore synthesis and characterization.

\section{Metal peroxo systems}

This section refers to electrophilic peroxo complexes of $\mathrm{d}^{0}$ metals, which are formed by several elements under $\mathrm{Ti}, \mathrm{V}, \mathrm{Cr}$, and $\mathrm{Mn}$ in the periodic table, the relevant oxidation state being favored as one moves to the left and down each row. Nucleophilic $\mathrm{d}^{8}$ peroxo complexes, while also catalytic, are not believed to compare with these in commercial potential.

(C) 2000 IUPAC, Pure and Applied Chemistry 72, 1289-1304 


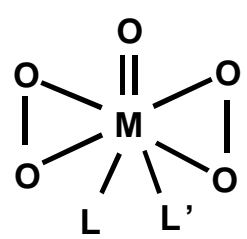

Catalysis using tungsten (VI) and molybdenum (VI) complexes, through formation of peroxo-metal intermediates, has been known for over 50 years, but important advances continue to be made in understanding and improving this mode of $\mathrm{H}_{2} \mathrm{O}_{2}$ activation. It is, in fact, one of the most versatile systems, and comes closest to classical organic peracids in its range of applications. The key catalytic intermediate is an $h_{2}$-peroxometal species (one or two peroxo groups are usually attached in this way) which acts on the substrate either directly or via protonation to give the $\mathrm{M}-\mathrm{O}-\mathrm{O}-\mathrm{H}$ species. Substrates may be coordinated to the metal center (e.g., in alcohol oxidation, by hydride abstraction) or uncoordinated (e.g., in epoxidation, according to the consensus of opinion).

Both molybdenum and tungsten work effectively in aqueous systems, unlike many catalysts, owing to their high affinity for $\mathrm{H}_{2} \mathrm{O}_{2}$. If the substrate is hydrophobic, two-phase systems are commonly used, the peroxo-complex being taken into organic by suitable ligands and/ or cationic phase transfer agents. The simple complexes are moderately active in epoxidation [88], $\mathrm{N}$-oxidation, alcohol oxidation etc, with tungsten being better except for the last of these. Activity can sometimes be raised by increasing temperature (to reflux in water), but this is not a good option for epoxidation owing to hydrolytic ring-opening. A key discovery, by Venturello [30], was the use of phosphate/ tungstate mixtures, which epoxidized terminal olefins at moderate temperatures. This boosts activity by making the peroxo-intermediate asymmetric, through nonbonded tungsten-oxygen interaction, facilitating oxygen transfer [31]. Industrial use of this system is certainly feasible [32].

Since the discovery of this structural feature, it has been reproduced in many other complexes, including $\mathrm{XM}_{2}$ and $\mathrm{XM}_{3}$ types $(\mathrm{X}=\mathrm{P}, \mathrm{As}, \mathrm{S})$ [33]. There are drawbacks, however. The non-bonded interaction is the basis for the stability of the complex, which therefore dissociates after the peroxo-group is lost, suggesting that a significant excess of $\mathrm{H}_{2} \mathrm{O}_{2}$ be maintained. This can lead to further oxidation by Hock reaction with the epoxide, giving -C--C- cleavage (though this itself can be a desirable transformation [34]. Hydrolytic ring-opening can be a problem for sensitive epoxides, owing to acidity of the medium and/ or Lewis acid character of the $\mathrm{d}^{0}$ metal center.

Excess $\mathrm{H}_{2} \mathrm{O}_{2}$ with tungsten, and particularly molybdenum, complexes can lead under some conditions to liberation of singlet oxygen - a particularly convenient and controllable source of the latter [35].

Simple immobilization of molybdenum or tungsten complexes on solids gives materials which oxidize "easy" substrates such as sulfides or electron-rich olefins [36], but as noted earlier, these are not of much interest for industrial chemical synthesis. In principle, it should be possible to attach $\mathrm{XW}_{2}$ complexes covalently to solid supports. This remains a serious and worthwhile research target, but successful catalysts based on this feature have not yet been reported.

A much more recently-discovered (by Herrmann et al.) catalyst based on peroxo-metal chemistry is methylrhenium (VII) oxide ( $\mathrm{MeReO}_{3}$, MTO) [37]. The alkyl substitution is critical to catalytic activity, which is mainly lost on degradation-owing to formation of unreactive rhenate, $\mathrm{ReO}_{4}^{-}$. MTO is a stronger Lewis acid than molybdenum or tungsten complexes, and catalyzes many reactions as such, including olefin metathesis. Its strong electrophilic nature makes the peroxo complexes good oxygentransfer species to olefins, etc., but the acidity also increases ring-opening, giving diol rather than epoxide as the product. However, unusual effects of azine ligands, including pyridines, bipyridines, etc., have been found, which appear to accelerate epoxidation but inhibit acid-catalyzed ring-opening [38]. The system is further complicated by gradual oxidation of these ligands to $N$-oxides [39], a common reaction of peroxo-metal oxidants. A full explanation is probably still lacking, but a lot of good information has been generated.

MTO is less tolerant of water than Mo and W systems, and requires strong to anhydrous $\mathrm{H}_{2} \mathrm{O}_{2}$ for best results. The ratio of $\mathrm{H}_{2} \mathrm{O}_{2}$ to $\mathrm{H}_{2} \mathrm{O}$ and catalyst influences equilibria between mono and diperoxo 
complexes, which can exhibit different activities-more so than molybdenum, for example, where the mono-peroxo tends to disproportionate. Degradation probably occurs via loss of a proton from the methyl group, then electrophilic attack on the $\mathrm{H}_{2} \mathrm{C}=\mathrm{Re}$ bond.

In addition to forming a fibrous solid polymer itself, monomeric MTO has been successfully supported on a range of solid surfaces, retaining its catalytic properties [40]. None of these catalysts has been developed for industrial use to date, and gradual degradation of the MTO is obviously a concern if long lifetimes are to be reached, but there remains scope for further research to this end.

Somewhat different properties to the above are offered by vanadium $(\mathbf{V})$ complexes [41], which also readily form peroxo-complexes with $\mathrm{H}_{2} \mathrm{O}_{2}$, but which are generally more selective catalysts with tbutyl hydroperoxide (TBHP) than with hydrogen peroxide (though, for example, enantioselective $\mathrm{S}$ oxidation can be achieved with chiral V-complexes and $\mathrm{H}_{2} \mathrm{O}_{2}$ ). Indeed, the $\mathrm{h}_{2}$-peroxo complexes of vanadium and molybdenum are themselves good catalysts for TBHP oxidations.

With $\mathrm{H}_{2} \mathrm{O}_{2}$, vanadium exhibits some 1 -electron $\left(\mathrm{V}^{\mathrm{V}-\mathrm{IV}}\right)$ redox chemistry, introducing free-radical character into its reactions. This makes epoxidation non-stereoselective, and can also change chemoselectivity. For example, when substituted in silicalites (see later), titanium (TS-1 and -2), oxidizes toluene mainly at the nucleus, giving cresols, whereas vanadium (VS-1 and -2) oxidizes more at the side-chain to give benzylic products - taken as evidence of parallel electrophilic and radical mechanisms [42]. This radical character can be useful, for example, in alcohol oxidations, where vanadium systems are more active than molybdenum, especially toward primary alcohols. Another chemoselectivity effect in silicalites concerns allylic alcohols, which are mainly epoxidized by TS-1 but undergo mainly alcohol oxidation by VS-1 [43].

Oxygen can be used as co-oxidant, since the radical intermediates can capture oxygen from the atmosphere, even to the extent where $\mathrm{H}_{2} \mathrm{O}_{2}$ is acting more as a radical initiator than a stoichiometric oxidant. The Fenton-like activity of vanadium complexes with azine carboxylic acids (2-picolinic acid, 4-heptyl-2-picolinic acid, and pyrazinecarboxylic acid) has been quite thoroughly explored [44], even extending to attack on methane [45].

A great deal of work has recently been reported on mimics of vanadium bromoperoxidase enzymes. Bromide with $\mathrm{V} / \mathrm{H}_{2} \mathrm{O}_{2}$ systems can provide an effective system for halogenation and for hydride abstractions such as alcohol oxidation, at moderate $\mathrm{pH}$ (uncatalyzed bromide and $\mathrm{H}_{2} \mathrm{O}_{2}$ only works in strong acid) [46]—molybdenum behaves similarly [47], as does MTO [83]. There is evidence for a bound active halogen species in both enzyme and mimics.

A final practical note is that, owing to the 1-electron chemistry, much more decomposition of excess $\mathrm{H}_{2} \mathrm{O}_{2}$ is caused in $\mathrm{V}$ systems than in $\mathrm{W}$, Mo and Re. This requires either better control of addition rates, or the effective capture and use of the oxygen generated, having regard for safety issues.

\section{Polyoxometallates and heteropolyanions}

This is a group of polynuclear oxoanion complexes usually based on tungsten or molybdenum. They often include structural heteroatoms, which may be di- to pentavalent, and one or more main atoms can be substituted by transition metals, giving additional 1- or 2-electron redox chemistry. Common structure types are Keggin $\left(\mathrm{XM}_{12}\right)$, Wells-Dawson $\left(\mathrm{X}_{2} \mathrm{M}_{18}\right)$, and "sandwich" $\left(\mathrm{M}_{9} \mathrm{X} . \mathrm{Y}_{4} \cdot \mathrm{XM}_{9}\right)$. They have the attraction of being fully inorganic and therefore not prone to oxidative degradation, though the equilibria involved in their formation are subtle and intricate. A bewildering range of structure options exist, where unit size, main and heteroatom,

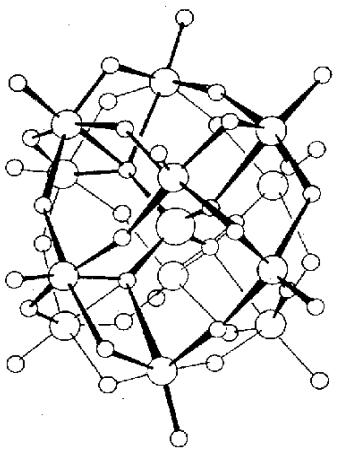
substituent, degree of substitution, and topomerism can all be varied.

Adding the Keggin complex, $\left[\mathrm{PW}_{12} \mathrm{O}_{40}\right]^{3-}$, catalyzes epoxidations with $\mathrm{H}_{2} \mathrm{O}_{2}$. However, it has been shown that the active species are the same as in the Venturello system (see earlier), arising from breakdown of the Keggin structure [48]. This illustrates two factors involved with 
polyoxometallate dissociation. Firstly, addition of $\mathrm{H}_{2} \mathrm{O}_{2}$ itself promotes dissociation, since it is a strong "ligand" for W and Mo. Secondly, dissociation is a nucleophilic process, and occurs readily when the complex has a relatively low charge. In fact, the silicon analog, $\left[\mathrm{SiW}_{12} \mathrm{O}_{40}\right]^{4}$, is much more stable, and does not catalyze epoxidation. Hydrolytic stability is therefore enhanced by high negative charges, and hence by lower-valent heteroatoms or substituents. Trivalent heteroatoms include B and Al, and divalent $\mathrm{Zn}$ and $\mathrm{Co}$ - these are very much more robust. As usual, there is also a cost—higher negative charge inhibits catalysis of electrophilic oxidations.

Since the early work, catalytic activity has now been shown for a variety of polyoxometallates, at least some of which appear to act in the undissociated form. Several substituted "lacunary" Keggin complexes have been studied [49], though the activity in epoxidations has usually been low for terminal olefins, where reported. The "sandwich" type has probably shown the greatest promise for epoxidations, in the form of the two complexes [WZnMn $\left.{ }_{2}^{\mathrm{II}}\left(\mathrm{ZnW}_{9} \mathrm{O}_{34}\right)_{2}\right]^{12-}[50]$ and $\left[\left(\mathrm{WZnRh}_{2}{ }_{2}\right)\left(\mathrm{ZnW}_{9} \mathrm{O}_{34}\right)_{2}\right]^{10-}[51]$, the latter offering lower $\mathrm{H}_{2} \mathrm{O}_{2}$ decomposition and greater stability.

Keggin complexes with a single transition metal substituent can give both radical and electrophilic reactions depending on the substituent, but reported activities are not of great interest industrially. A W-peroxo derivative of an intact singly substituted Keggin structure has now been discovered, $\beta_{3}$ $\left.\left[\mathrm{Co}^{\mathrm{II}} \mathrm{O}_{4}\right) \mathrm{W}_{11} \mathrm{O}_{31}\left(\mathrm{O}_{2}\right)_{4}\right]^{10-}[52]$. This appears, from cyclohexenol oxidation results, to be a relatively nucleophilic oxidant, as expected. Hydroxylations of alkanes are catalyzed by the substituted Keggin structure, $\left[\gamma-\mathrm{SiW}_{10}\left\{\mathrm{Fe}(\mathrm{OH})_{2}\right\}_{2} \mathrm{O}_{38}\right]^{6-}[53]$, and it is established by NMR that the 1,2-Fe topomer (with vicinal Fe atoms) is the main active component. Similar results are reported for oxygen oxidations with $\mathrm{H}_{5} \mathrm{PV}_{2} \mathrm{Mo}_{10} \mathrm{O}_{40}$, with the 1,2-V topomer being the best catalyst of phenol and alcohol oxidation, among others [54]. Both of these catalysts seem to involve cooperation between two 1-electron oxidizing species, as may others with this feature [55]. Mixed $\mathrm{Mo} / \mathrm{V}$ complexes up to $\mathrm{PV}_{6} \mathrm{Mo}_{6}$ catalyze phenol hydroxylation by $\mathrm{H}_{2} \mathrm{O}_{2}$ [56], and the dependence of o-:p- ratio on V:Mo ratio may well be related to topomer interactions.

An important development in the practical use of polyoxometallates, aimed thus far at paper pulp bleaching, is successful self-assembly-including self-repair and self-re-assembly after reaction, even if dissociation occurs at an intermediate stage [57]. This makes use of the thermodynamic stability of the complexes under given conditions, once an effective catalytic structure can be matched to those conditions. A lot of laborious research is needed to achieve this match, but it is ultimately one of the most valuable properties of polyoxometallates, and should ensure their adoption for many catalytic processes in future. This same feature suggests enormous potential in immobilized systems, as yet largely untapped. A limitation of polyoxometallates is their high equivalent weight as oxidizing intermediates. For this reason, true catalytic cycles, rather than stoichiometric generation/ use/ regeneration loops, remain a key target.

\section{Zeolitic and smectitic materials}

This section addresses heterogeneous catalysts with no homogeneous analog, as distinct from immobilized homogeneous catalysts. Some excellent critical reviews covering one or both areas have recently been published [58].

\section{Titanium and other silicalites}

TS-1 is a titanium-substituted aluminium-free silicalite with 5.5 $\AA$ channels (MFI structure, analogous to ZSM-5), found to catalyze many $\mathrm{H}_{2} \mathrm{O}_{2}$ oxidations [59]. After the first reports of titanium silicalite in the early 1980s, there was a huge research effort worldwide to find the many analogous materials believed to be waiting to be discovered. However, as time has progressed, TS-1 itself seems more and more unusual. Hence, this effort has not abated, but a large amount of it has in fact been applied to finding out why TS-1 works so well, before being in a position to make new breakthroughs [60]. This in itself has fuelled progress on characterization techniques for such materials [61].

(C) 2000 IUPAC, Pure and Applied Chemistry 72, 1289-1304 


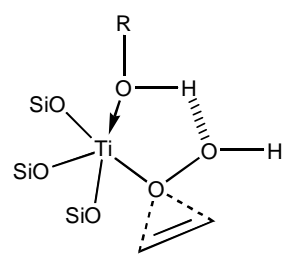

From the beginning, at least three features were potentially important: hydrophobic environment, tetrahedral geometry, and constrained reaction site. All of these have turned out to be relevant. Work on solvent dependence, and on Ti/ Si xerogels with varying hydrophobicity [62], confirms the importance of the active site environment, while not achieving comparable catalysis by the latter route. In fact, TS-1 has been commercialized for oxidation of phenol to catechol/ quinol, and for in situ oxidation of ammonia to hydroxylamine in production of caprolactam from cyclohexanone (via the oxime). It is likely also to be used for epoxidation of olefins in the future, an application made more attractive by the reduction in price of $\mathrm{H}_{2} \mathrm{O}_{2}$ during the 1990s. Methanol or water are the usual solvents [63]. For many applications, residual acidity must be suppressed, as it leads to fouling of the catalyst by overoxidized on hydrolyzed products. Post-addition of alkali-metal or other cations helps, without much impact on activity, implying that acid sites are mainly at the surface [64]. Site-isolation of the titanium atoms appears important, and the lower limit of 40:1 $\mathrm{Si}$ Ti excess $(\mathrm{m} / \mathrm{m})$ for good catalysts agrees well with this criterion-increased $\mathrm{H}_{2} \mathrm{O}_{2}$ decomposition and less substrate oxidation are otherwise seen. Regeneration of TS- 1 can be done effectively in the liquid phase, without recourse to re-calcination, by use of $\mathrm{H}_{2} \mathrm{O}_{2}$ in the absence of substrate [65]presumably this helps to degrade "heavies" fouling the channels into smaller molecules which can be desorbed. The physical form of the catalyst is critical, as in all industrial process, and the very small TS1 crystallites required for high activity must themselves be securely supported on a suitable substrate [87].

Other elements have been used in place of titanium in making silicalite catalysts; many of these are probably not true framework-substituted structures. ZrS-1 [66], SnS-1 [67] and MoS-1 [68] all show some catalytic activity, but fail to improve upon TS-1 for any particular oxidation. VS-1 does some useful additional chemistry, as noted earlier $[42,43]$. CrS- 1 shows activity in alcohol oxidations, but this has now been shown to arise from homogeneous catalysis from $\mathrm{Cr}$ leaching [83,111]. TS-2 is based on the MEL (ZSM-11) structure, and exhibits the same range of chemistry as TS-1, with some variations; these are not large enough to have caused its industrial exploitation to date.

TS-1 is a valuable and versatile catalyst, but with an important drawback of substrate size limitation. The zeolite channels will not accept o- or $\mathrm{m}$ - disubstituted aromatics, alicyclic terpenes or tertiary aliphatic compounds, and simple alicyclics or branched aliphatics pass with difficulty, restricting desorption of product and therefore reaction rate. For this reason alone, the search for alternatives is bound to continue.

\section{Other titanium catalysts}

The most useful such material found to date is Ti- $\beta$, a large-pore zeolite (6.4-7.6 $)$ [70] containing framework Ti, though the cavity size also accommodates other forms of Ti. By comparison with TS-1, it certainly accepts large substrate molecules, but it is not as hydrophobic, and does not exclude solvent from the reaction site-hence solvent effects are very significant [71]. The lower hydrophobicity favors acid-catalyzed ring-opening of epoxides, giving diols or their monoethers as the main products from olefins [72]. The acidity can be suppressed by working in the mildly-basic acetonitrile as solvent (selectivity is more solvent-dependent for Ti- $\beta$, and trifluoroethanol is also a good choice), and by addition of cations [73]. In the latter case, activity is reduced, which confirms that the acidity is in the cavities, adjacent to active sites. Presence of solvent in the cavities also reduces activity, and Ti- $\beta$ is slower than TS-1 at oxidizing small substrates: in fact, it is a better catalyst for TBHP reactions, the latter being more hydrophobic than $\mathrm{H}_{2} \mathrm{O}_{2}$. However, Ti- $\beta$ is now quite well enough understood to find application in fine chemistry as a convenient catalyst for larger molecule oxidations, etc. [74]. Furthermore, the cavities are large enough to allow some surface modification, to increase hydrophobicity or attach other functional groups, while maintaining a viable volume.

The incorporation of titanium into even larger cavities [75], such as the mesomorphous MCM and HMS series made using liquid crystal templates, yields materials which, according to reports to date,

(C) 2000 IUPAC, Pure and Applied Chemistry 72, 1289-1304 
are still less good with $\mathrm{H}_{2} \mathrm{O}_{2}$ and better with TBHP than Ti- $\beta$, for reasons similar to those discussed. The same options for modifying surface [76] and spatial properties exist. The subject of design of large-pore materials has been reviewed [84], and several catalysts based on them investigated [85], results being largely consistent with the picture presented here.

\section{Other metals and supports}

Zeotypes APO and SAPO have been explored to some extent as supports for liquid phase oxidation catalysts. APOs such as VPI-5 can incorporate a variety of transition metals such as vanadium (P substitution) cobalt (Al substitution or cation exchange), or $\mathrm{Cr}$, and are large-pore materials. However, the structures are not particularly robust, and rely for their integrity on a large amount of coordinated water. Overall, published results do not demonstrate any advantage over zeolitic supports. CrAPO suffers $\mathrm{Cr}$ leaching in use with $\mathrm{H}_{2} \mathrm{O}_{2}$, just as CrS-1 [58c,69].

A rather more encouraging theme is that of metal $(\mathrm{IV}, \mathrm{V})$ phosphates such as zirconium, tin, cerium, and vanadium. Taking zirconium phosphate as an example, this readily forms a layered (smectitic) structure in which the interlayer spaces ( $7.6 \AA$ spacing) contain strong Brønsted acid sites, corresponding to the protons in the empirical formula $\mathrm{ZrPO}_{4}(\mathrm{OH})$. Such materials, whether overtly crystalline or amorphous according to XRD spectroscopy, activate $\mathrm{H}_{2} \mathrm{O}_{2}$ towards electrophilic oxidations. Examples

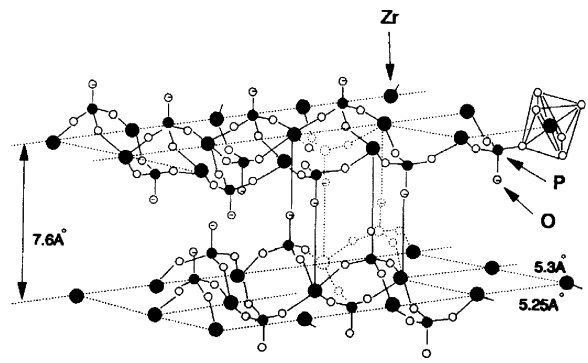
include phenol hydroxylation [77], where performance compares well with TS-1, and Bäyer-Villiger reactions. In some cases, acetic acid is found to be the best solvent, and there is evidence that peracetic acid is formed in the interlayers and reacts directly with the substrate there. In other cases, acetonitrile is a good solvent, and the chemistry appears to arise from protonated hydrogen peroxide itself. The interlayer spaces are relatively hydrophilic and acidic, so olefins are more likely to give diols than epoxides in this system. However, these spaces can be modified by pillaring (organic or inorganic) to give a range of heights and polarities. Some variation is also possible by templating with nonionic or cationic surfactants. Like polyoxometallates, there is enormous scope for structure manipulation. Combinations of major and minor elements, crystallinities, etc. can be made, but the potential of this type of catalyst for use with $\mathrm{H}_{2} \mathrm{O}_{2}$ has been much less explored to date. One of their chief attractions compared to TS- 1 is the greater mobility and size of substrates achievable.

Other smectitic materials include clays, for example, montmorillonite (acid sites), and layered double hydroxides, for example, gibsonite (base sites). These have been employed as supports for other catalysts, the former for cationic species such as bpy and tacn complexes, the latter (which are only stable over a narrow neutral to alkaline $\mathrm{pH}$ range) for anionic species such as polyoxometallates and metal peroxo complexes.

\section{Enzymes}

Given the enormous progress in biotechnology, and the receptiveness of much of the chemical industry towards it, such a review as this should address this area. In fact, oxidoreductase enzymes are plentifulmany are well characterized and readily isolated — but they are hard to use here.

Firstly, most enzymes are not designed to withstand significant concentrations $(\geq 1 \%)$ of $\mathrm{H}_{2} \mathrm{O}_{2}$. In nature, for example, $\mathrm{H}_{2} \mathrm{O}_{2}$ is often generated from dioxygen reduction by oxygenases, but invariably there is co-production of catalase, which destroys the $\mathrm{H}_{2} \mathrm{O}_{2}$ very efficiently without release of other active oxidants. Peroxidase enzymes do exist, of course, using $\mathrm{H}_{2} \mathrm{O}_{2}$ itself to carry out organic oxidations, but again these work naturally with small peroxide concentrations, and are not very robust to oxidation-supported or immobilized catalysts have a strictly limited life. In some cases, such as ligninases, self-destruction is even a normal part of the mode of action. This drawback could conceiv- 
ably be overcome by using whole cell systems rather than isolated enzymes: such expertise is not widespread in the chemical industry at present.

Secondly, the low concentration limit and high catalyst molecular weight mean that space yield is poor and recovery/ recycle of enzyme is awkward. Hence, peroxidases as such are not particularly attractive as catalysts in industrial oxidation. This applies particularly to haem-based systems. Vanadium and molybdenum enzymes are somewhat more robust, but also less active towards substrates of industrial interest (see Issues section). Peroxidases do have other applications in synthesis [78].

Of distinct interest, however, are hydrolase (lipase, esterase) enzymes - not for catalyzing $\mathrm{H}_{2} \mathrm{O}_{2}$ reactions directly but for forming more electrophilic intermediates, through acylation of $\mathrm{H}_{2} \mathrm{O}_{2}$ (or "esterification" of acids with $\mathrm{H}_{2} \mathrm{O}_{2}$ to give peracids). These enzymes are much more robust, and one in particular, Candida Antarctica lipase, is outstandingly so, such that it has a long lifetime in immobilized form (Novozym ${ }^{\mathrm{TM}} \mathbf{4 3 5}$ ). A range of peracids has been generated this way, either from their acids or from lower alkyl esters. Peracetic acid works reasonably well, but longer-chain analogs suit the enzyme better, especially $\mathrm{C}_{8}$ and greater. Methyl oleate reacts in two stages, the intermediate peracid epoxidizing itself to form 9,10-epoxystearic acid [80]. Furthermore, acid-sensitive substrates can be oxidized by a percarbonic acid intermediate generated from dialkyl (e.g., dimethyl) carbonates and $\mathrm{H}_{2} \mathrm{O}_{2}$; after reaction, only alcohol and $\mathrm{CO}_{2}$ are left [81].

\section{CONCLUSIONS}

The author being, on the whole, an optimist, this section is likely to be a mixture of what is desirable and what is likely. The first point should serve to convince on this point: greater cooperation between the practitioners of homogeneous and heterogeneous catalysis must be achieved. There is now a lot of rigorous study of the behavior of molecules at active sites by the "molecular catalysis" camp. There also remain many naïve attempts to immobilize catalysts with little regard for the influence of the surface or steric environment, including the apparent assumption that surface concentrations of reactants will be similar to those in the bulk liquid medium. Heterogeneous catalysis expertise (mainly, of course, from the gas phase) has a bigger part to play than so far realized. Maybe the mutually beneficial progress in characterization techniques can form the bridge between these two estranged disciplines.

To be more specific on the systems discussed, the basic belief is that industry will increasingly focus research, and particularly development, on fully inorganic systems. Hence, there will be little impact at the large scale from catalytic complexes with organic ligands, or from enzymes, even though these will improve further in robustness. Some uses of supported organic complexes in fine chemical oxidations, on the other hand, are quite possible.

The four main "battlegrounds", upon which new territory may be claimed for catalytic technology using hydrogen peroxide, are believed to be as follows:

- Further progress is due on surface modification of large-pore materials to get Ti catalysts closer to the performance of TS-1 for large molecules.

- There is a good possibility of successful immobilization of interactive $\mathrm{XM}_{2}$ peroxo complexes (especially for $\mathrm{M}=\mathrm{W}$ ) to obtain Venturello activity in heterogeneous form. MTO will remain essentially a small-scale catalyst, owing to the organic content as noted above.

- The potential for smectitic or layered catalytic materials will be more fully explored, as the field of zeolites and mesopores is increasingly crowded.

- Polyoxometallate-supported catalytic species - containing redox metals such as $\mathrm{Mn}, \mathrm{Co}$, and Vwill become much more important, as ways to optimize reactivity and to manage association/ dissociation equilibria are mastered.

The story continues to unfold, and will test the accuracy of these predictions.

(C) 2000 IUPAC, Pure and Applied Chemistry 72, 1289-1304 


\section{REFERENCES}

1. Website addresses: (a) http://www.acs.org/education/greenchem/principles.html; (b) http:// www.chemsoc.org/networks/gcn/about.htm; (c) http://www.rsc.org/is/journals/current/green/ editorial.htm

2. (a) R. A. Sheldon. Chem. Ind. 12, (1997); (b) idem, CHEMTECH 3, 38-47 (1994) and loc cit.

3. Reactivity is strongly influenced by "spin bottlenecks", originating from the triplet ground state of dioxygen: metal species formed from dioxygen and hydrogen peroxide, as well as the oxidants themselves, often differ in this respect. See e.g., (a) A. Fiedler, I. Kretschmar, D. Schroder, H. Schwarz, J. Am. Chem. Soc. 118, 9941 (1996); (b) M. Filatov, N. Harris, S. Shaik. Angew. Chem. Int. Ed. Engl, 1999, 38, 3510.

4. Recent longer reviews: (a) J. Mlochowski and S. B. Said. Polish J. Chem. 71, 149-69 (1997); (b) M. G. Clerici. In Catalysis and Fine Chems III, M. Guisnet et al. (Eds.), pp. 21-33, Elsevier (1993); (c) I. I. Moiseev. J. Mol. Cat. A: Chem. 127, (1-3), 1-23 (1997).

5. See (a) A. Tuel. Stud. Surf. Sci. Catal. 117, 159-70 (1998); (b) R. A. Sheldon, M. Wallau, I. W. C. E. Arends, U. Schuchardt. Acc. Chem. Res. 31, 485-93 (1998).

6. An indicative order of reactivity is cyclooctene $>$ methylcyclohexene $>$ cyclohexene $>2$-octene $>1$-octene > allyl chloride

7. Recent reviews: (a) A. M. D’A Rocha Gonsalves and M. M. Pereira. J. Mol. Cat. A: Chem. 113, 209-11 (1996); (b) R. A .Sheldon (Ed.). Metalloporphyrins in Catalytic Oxidations, Marcel Dekker, New York (1994).

8. (a) T. G. Traylor and S. Tsuchiya. Inorg. Chem. 26, 1338 (1987); (b) M-N. Carrier, C. Scheer, P. Gouvine, J-F. Bartoli, P. Battioni, D. Mansuy. Tetrahedron Lett. 31, 6445 (1990).

9. (b) K. Ozette, P. Battioni, P. Leduc, J-F. Bartoli, D. Mansuy. Inorg. Chim. Acta 272, 4-6 (1998).

10. A. M. d'A Rocha Gonsalves, R. A .W. Johnstone, M. M. Pereira, J. Shaw, A. J. F. N. Sobral. Tetrahedron Lett. 32, 1355 (1991).

11. (a) K. A. Lee and W. Nam. J. Am. Chem. Soc. 119 (8), 1916-22 (1997); (b) Y. J. Lee, Y. M. Goh, S-Y. Han, C. Kim, W. Nam. Chem Lett. 837-8 (1998).

12. J. Bernadou and B. Meunier. Chem. Comm. 2167-73 (1998).

13. (a) L. Barloy, J. P. Lallier, P. Battioni, D. Mansuy. New J. Chem. 16, 71 (1992); (b) S. Campestrini and B. Meunier. Inorg. Chem. 31, 1999 (1992).

14. (a) R. Song, A. Robert, J. Bernadou, B. Meunier. Inorg. Chim. Acta 272, 228-74 (1998); (b) S. J. Yang and W. Nam. Inorg. Chem. 37(4), 606-7 (1998); (c) Y. M. Goh and W. Nam. Inorg. Chem., 38(5), 914-20 (1999); (c) W. Nam, Y. M. Goh, Y. J. Lee, M. H. Lim, C. Kim. Inorg. Chem. 38(13), 3238-40 (1999); and ref. 11 (a,b).

15. M. A. Martinez-Lorente, P. Battioni, W. Kleemiss, J-F. Bartoli, D. Mansuy. J. Mol. Cat. A: Chem, 113, 343-53 (1996).

16. J. T. Groves, M. Bonchio, T. Carofiglio, K. Shalyaev. J. Am. Chem. Soc. 118, 8961-2 (1996).

17. E. Larsen and K. A. Jorgensen. Adv. Chem. Ser. 43, 259 (1989).

18. (a) A. Hadasch, A. Sorokin, A. Rabion, L. Fraisse, B. Meunier. Bull. Soc. Chim. Fr. 134, 1025-32 (1998); (b) idem, New J. Chem. 22, 45-51 (1998); (c) E. Armengol, A. Corma, V. Fornes, H. Garcia, J. Primo. Appl. Cat. A: Gen. 181(2), 305-12 (1999); (d) N. S. Zefirov and A. N. Zakharov. Can. J. Chem. 76(6), 955-9 (1998).

19. (a) D. E. De Vos and T. J. Bein. Chem. Commun. 917-8 (1996); (b) idem, J. Organomet. Chem. 520(1-2), 195-200 (1996); (c) C. Zondervan, R. Hage, B. L. Feringa. ibid, 687-8 (1997).

20. (a) C. P. Horwitz, D. R. Fooksman, L. D. Vuocolo, S. W. Gordon-Wylie, N. J. Cox, T. J. Collins, 
J. Am. Chem. Soc., 120, 4867-8 (1998); (b) C. G. Miller, S. W. Gordon-Wylie, S. A. Strazisar, D. K. Peraino, G. R. Clark, S. T. Weintraub, T. J. Collins. Ibid., 120, 11540-1 (1998); (c) U.S. Patent No 5847120 (1998)

21. (a) International Patent Application 93/00319 (Solvay Interox); (b) C. W. Jones, A. Hackett, I. Pattinson, A. Johnstone, S. L. Wilson. J. Chem. Res. (S), 428 ((M) 2501) (1996).

22. (a) International Patent Application 94/02080 (Solvay Interox); (b) C. W. Jones, W. R. Sanderson, K. Auty, B. C. Gilbert, B. C. Thomas, S. W. Brown, J. Mol. Cat. A: Chem., 117, 279 (1997).

23. (a-c) European Patents 334511, 336567, 336568; U.S. Patent 4943358 (all to Solvay Interox); (d) C. W. Jones, N. G. Carter, S. C. Oakes, S. L. Wilson, A. Johnstone. J. Chem. Technol. Biotechnol. 71, 111 (1998).

24. For critical reviews see D. E. De Vos, F. Thibault-Starzyk, P. P. Knops-Gerrits, R. F. Parton, P. A. Jacobs, Macromol. Symp., 80, 157-84 (1994); ref 5(a).

25. (a) Co: E. Armengol, A .Corma, V. Fornes, H. Garcia, J. Primo. Appl. Cat. A: Gen. 181(2), 30512 (1999); (b) Cu: R. Raja and P. Ratnasamy. Appl. Catal. A: Gen. 143, 145-58 (1996); (c) Fe: Ref. 18 (c); (d) Mn: S. Ernst and B. Jean. Progr. Zeol. Microp. Mater. 105, 747-54 (1997); (e) V: A. Kozlov, K. Asakura, Y. Iwasawa. J. Chem. Soc. Faraday Trans. 94(6), 809-16 (1998).

26. (a) J. Xiao, J. Xu, Z. Gao, Catal. Lett. 57, 37-42 (1999); (b) B. F. Sels, D. E. De Vos, P. A .Jacobs, Tetrahedron Lett. 37(47), 8557-60 (1996).

27. S-S. Khim, W. Zhang, T. J. Pinnavaia. Catal. Lett. 43, 149-54 (1997).

28. D. E. De Vos, S. De Wildeman, B. F. Sels, P. J. Grobet, P. A. Jacobs. Angew. Chem. Int. Ed. Engl. 38(7), 980-3 (1999).

29. P. P. Knops-Gerrits, I. F. J. Vankelecom, E. Beatse, P. A. Jacobs. Catal. Today 32(1-4), 63-70 (1996).

30. C. Venturello and R. D'Aloisio. J. Org. Chem. 53, 1553 (1988).

31. L. Salles, F. Robert, V. Semmer, Y. Jeannin, J-M. Brégeault. Bull. Soc. Chim. Fr. 133, 319-28 (1996).

32. e.g., (a) U.S. Patent 5763629 (Sartomer, F. Mingxin et al.); (b) U.S. Patent 5780655, 1998 - W. P. Shum (ARCO); (c) Solvay Interox, unpublished information.

33. (a) J.-Y. Piquemal, C. Bois, J.-M. Brégeault. Chem. Commun. 473-4 (1997); (b) J-Y. Piquemal, L. Salles, C. Bois, F. Robert, J.-M. Brégeault. C R Acad. Sci. Paris, 319 (II), 1481-7 (1994).

34. E. Antonelli, R. D'Aloisio, M. Gambaro, T. Fiorani, C. Venturello. J. Org. Chem. 63, 7190-206 (1998).

35. (a) J.-M. Aubry and S. Bouttemy. J. Am. Chem. Soc. 119(23), 5286-94 (1997); (b) V. Nardello, J. Marko, G. Vermeersch, J.-M. Aubry. Inorg. Chem. 37(21), 5418-23 (1998) and loc cit.

36. (a) J.-M. Brégeault, R. Thouvenot, S. Zhougebi, L. Salles, A. Atlamsani, E. Duprey, C. Aubry, F. Robert, G. Chottard. In New Developments in Selective Oxidation II, V. Cortés-Corberán and S. Vic Bellón, (Eds.), pp. 571-581, Elsevier (1994); (b) R. S. Drago and D. S. Burns. J. Catal. 166(2), 177-9 (1997); (c) G. Gelbard, F. Breton, M. Quenard, D. C. Sherrington. J. Mol. Cat. A: Chem. 2457 (1999); (d) G. Gelbard, D. C. Sherrington, F. Breton, M. Benelmoudeni, M.-T. Charreyre, D. Dong. Metal-Containing Polymeric Materials (Proc. Int. Symp.), pp. 265-75, Plenum (1996); (d) G. Gelbard, F. Breton, M. Benelmoudeni, M. Quenard. React. Funct. Polym. 33, 11725 (1997).

37. Recent reviews: (a) J. H. Espenson and M. M. Abu-Omar. Adv. Chem. Ser. 253, 99-134 (1997); (b) J. H. Espenson. Chem. Commun. (6), 479-88 (1999).

38. (a) J. Rudolph, K. L. Reddy, J. P. Chiang, K. B. Sharpless. J. Am. Chem. Soc. 119, 6189-90 (1997); (b) C. Copéret, H. Adolfsson, K. B. Sharpless. Chem. Commun. 1565-6 (1997); (c) W. A.

(C) 2000 IUPAC, Pure and Applied Chemistry 72, 1289-1304 
Herrmann, R.W. Fischer, M. U. Rauch, W Scherer. J. Mol. Cat. A: Chem. 86(1-3), 243-66 (1994); (d) W.-D. Wang and J. H. Espenson. J. Am. Chem. Soc. 120, 11335-41 (1998); (e) M .Nakajima, Y. Sasaki, H. Iwamoto, S. Hashimoto. Tetrahedron Lett. 39(1-2), 87-8 (1998); (f) A. Deloffre, S. Halut, L .Salles, J.-M. Brégeault, J. R. Gregorio, B. Denise, H. Rudler. J. Chem. Soc. Dalton Trans. 2897-8 (1999); (g) H. Rudler, J. R. Gregorio, B. Denise, J.-M. Brégeault, A. Deloffre. J. Mol. Cat. A: Chem. 133, 255-65 (1998).

39. (a) R. W. Murray, K. Iyanar, J. Chen and J. T. Wearing. Tetrahedron Lett. 37(6), 805-8 (1996); (b) C. Copéret, H. Adolfsson, J. P. Chiang, A. K. Yudin, K. B. Sharpless. Tetrahedron Lett. 39, 7614 (1998).

40. Z. Zhu and J. H. Espenson. J. Mol. Cat. A: Chem. 121, 139-43 (1997).

41. V. Conte, F. Di Furia, G. Licini. App. Catal. A: Gen. 157, 335-61 (1997).

42. A. V. Ramaswamy, S. Sivasanker and P. Ratnasamy, Div Petr Chem Symp, $106^{\text {th }}$ Natl Meeting ACS, Chicago 1993, p. 765, quoted in ref. 58(a).

43. A. Bhaumik, R. Kumar and P. Ratnasamy. Stud. Surf. Sc. Catal. 84, 1883-8 (1994).

44. (a) G. B. Shul'pin, D. Attanasio, L. Suber. J. Catal. 142, 147-52 (1993); (b) G. B. Shul'pin, M. C. Guerreiro, U. Schuchardt., Tetrahedron 52(41), 13051-62 (1996); (c) U. Schuchardt, M. C. Guerreiro, G. B. Shul'pin. Russ. Chem. Bull. 47(2), 247-52 (1998).

45. (a) G. V. Nizova, G. Süss-Fink, G. B. Shul'pin. Chem. Commun. 397-8 (1997); (b) idem, Tetrahedron 53(10), 3603-14 (1997).

46. V. Conte, F. Di Furia, S. Moro, S. Rabbolini. J. Mol. Cat. A: Chem. 113, 175-84 (1996).

47. M. Bhattercharjee and J. Mukherjee. J. Chem. Res. (S) (6), 238-9 (1995).

48. (a) C. Aubry, G. Chottard, N. Platzer, J.-M. Brégeault, R. Thouvenot, F. Chauveau, C. Huet, H. Ledon, Inorg Chem 30, 4409-15 (1991); (b) L. Salles, C. Aubry, R. Thouvenot, F. Robert, C. Dorémieux-Morin, G. Chottard, H. Ledon, Y. Jeannin, J.-M. Brégeault. ibid, 33, 871-8 (1994); (c) L. Salles, J.-Y. Piquemal, R. Thouvenot, C. Minot, J.-M .Brégeault. J. Mol. Cat. A: Chem. 117(1-3), 375-87 (1997).

49. (a) T. Yamase, E. Ishikawa, Y. Asai, S. Kanai, J. Mol. Cat. A: Chem. 114(1-3), 237-45 (1996); (b) L. I. Kuznetsova, L. G. Detusheva, N. I. Kuznetsova, M. A. Fedotov, V. A. Likholobov. J. Mol. Cat. A: Chem. 117, 389-96 (1997); (c) N. I. Kuznetsova, L. I. Kuznetsova, V. A. Likholobov. J. Mol. Cat. A: Chem. 108, 135-43 (1996); (d) M. M. Q. Simões, C. M. M. Conceição, J. A. F Gamelas, P. M. D. N. Domingues, A. M. V. Cavaleiro, J. A. S. Cavaleiro, A. J. V. Ferrer-Correia, R. A. W Johnstone. J. Mol. Cat. A: Chem. 144, 461-8 (1999).

50. R. Neumann and D. Juwiler. Tetrahedron 52(26), 8781-8 (1996).

51. R.Neumann and A. M. Khenkin. J. Mol. Cat. A: Chem. 114, 169-80 (1996).

52. J. Server-Carrió, J. Bas-Serra, M. E. Gonzáles-Núñez, A. García-Gastaldi, G. B. Jameson, L .C. W. Baker, R Acerete. J. Am. Chem. Soc. 121, 977-84 (1999).

53. N. Mizuno, C. Nozaki, I. Kiyoto, M. Misono. J. Am. Chem. Soc. 120, 9267-72 (1998); N. Mizuno, I. Kiyoto, C. Nozaki, M. Misono. J. Catal. 181, 171-4 (1999).

54. A. M. Khenkin and R. Neumann, results presented at the Activation of Dioxygen and Homogeneous Oxidation Conference 1999 (ADHOC-99), York, UK.

55. (a) A. Atlamsani, M. Ziyad, J.-M. Brégeault. J. Chem. Phys. 1995, 92, 1344-64; (b) X. Zhang and C. L. Hill, Chemical Industries (Dekker) 1998, 75, 519-24

56. (a) International Patent Application 92/14691 (Solvay Interox); S. W. Brown, A. Hackett, A. Johnstone, A. M. King, K. M. Reeve, W. R. Sanderson, M. Service. Tagungsbericht 9204 Proc. DGMK Conference, "Selective Oxidation in Petrochemistry", p. 339, M. Baerns and I.Weitkamp (Ed.), Goslar (1992). 
57. (a-e) U.S. Patents 5,302,248, 5,549,789, 5,552,019, 5,695,605, 5,824,189 (I. A. Weinstock, C. L. Hill); (f) C. L. Hill and X. Zhang. Nature 373, 324-6 (1995); (g) I. A. Weinstock, R. H. Atalla, R. S. Reiner, M. A. Moen, K. E. Hammel, C. J. Houtman, C. L. Hill, M. K. Harrup. J. Mol. Catal. A: Chem. 116, 59-8 (1997).

58. (a) D. Dumitriu, E. Angelescu, V. I. Parvulescu. Roum. Chem. Quart. Rev. 6(2), 113-31 (1998); (b) J. H. Clark and D. J. Macquarrie. Org. Proc. Res. Dev. 1, 149-62 (1997); (c) R. A. Sheldon, I. W. C. E. Arends, H. E. B. Lempers. Catal. Today 41, 387-407 (1998); (d) idem, Collect. Czech. Chem. Commun., 63, 1724-42 (1998); (e) S. L. Wilson, C. W. Jones. Stud. Surf. Sci. Catal. 110, 603-13 (1997); (f) I .W. C. E. Arends, R. A. Sheldon, M .Wallau, U. Schuchardt. Angew. Chem. Int. Ed. Engl. 36, 1144-63 (1997).

59. (a) B. Notari. Catal. Today 18, 163 (1993); (b) M. G. Clerici and P. Ingallina. J. Catal. 140(1), 71 (1993).

60. (a) T. Tatsumi, K. Yanagisawa, K. Asano, M. Nakamura, H. Tominaga. Stud. Surf. Sci. Catal. 83, 417-24 (1994); (b) G. M. Zhidomirov, A. V. Arbuznikov, I. V. Yudanov, N. A. Kachurovskaya. React. Kinet. Catal. Lett. 57(2), 263-74 (1996); (c) E. Hoeft, H. Kosslick, R. Fricke, H.-J. Hamann. J. Prakt. Chem. 338(1), 1-15 (1996); (d) E. Duprey, P. Beaunier, M.-A.. Springuel-Huet, F. BozonVerduraz, J. Fraissard, J.-M. Manoli, J.-M. Brégeault. J. Catal. 165, $22-32$ (1997).

61. (a) E. P. Talsi, New J. Chem. 21(6-7), 709-25 (1997); (b) J. M.Thomas and D. E. W. Vaughan, J. Phys. Chem. Solids 50(5), 449-67 (1989).

62. W. F. Maier. Prepr. Symp., Am. Chem. Soc., Div. Fuel Chem. 43(3), 534-7 (1998).

63. Acetone has been advocated by some, pointing out that the hydroperoxides it forms with $\mathrm{H}_{2} \mathrm{O}_{2}$ are useful secondary oxidants. However, there is the risk of build-up of condensed organic peroxides that are highly dangerous, and the use of acetone is therefore strongly discouraged.

64. Europ. Patent 230949 (M. G. Clerici, U. Romano, Enichem)

65. (a) German Patent DE 19528220 (G. Thiele, Degussa); (b) G. F. Thiele and E. Roland. J. Mol. Cat. A: Chem. 117(1-3), 351-6 (1997).

66. UK Patent GB 2332364 A. (G. M. K. Mathys, J. M. Dakka et al, Exxon).

67. (a,b) U.S. Patents 5780654, 5354875 (L. Nemeth et al, UOP); ref 58 (c).

68. P. S. Ranghavan, V. Ramaswamy, T. T. Upadhya, A. Sudalai, A. V. Ramaswamy, S. Sivasanker. J. Mol. Cat. A: Chem. 122, 75-80 (1997).

69. R. A. Sheldon, M. Wallau, I. W. C. E. Arends, U. Schuchardt. Acc. Chem. Res. 31, 485-93 (1998); ref 58 (c).

70. Large-pore zeolite review: M. A. Camblor, M. Costantini, A. Corma, P. Esteve, L. Gilbert, A. Martínez. Roots of Organic Development, Vol. 8, pp 391-404 (1996).

71. (a) A. Corma, P. Esteve, A. Martínez. J. Catal. 161(1), 11-19 (1996); (b) M. A. Camblor, A. Corma, P Esteve, A. Martínez, S Valencia. Chem. Commun. 795-6 (1997).

72. E. G. Derouane, G. J. Hutchings, W. F. Mbafor, S. M. Roberts. New J. Chem. 22(8), 797-9 (1998).

73. T. Sato, J. Dakka, R. A. Sheldon. Stud. Surf. Sci. Catal. 84, 1853-60 (1994), quoted in ref 58 (f).

74. (a) J. C. van der Waal, M. S. Rigutto, H. van Bekkum. Appl. Cata.l A: Gen. 167, 331-42 (1998); (b) A. Corma, P. Esteve, A. Martínez. Applied Catal. A: Gen. 143, 87-100 (1996).

75. Mesoporous material review: A. Corma and D. Kumar. Stud. Surf. Sci. Catal. 117, 201-22 (1998).

76. M. D. D'Amore and S. Schwarz. Chem. Commun. 121-2 (1999).

77. (a) A. Johnstone, P. J. Middleton, R. C. Wasson, R. A. W. Johnstone, P. J. C. Pires, G. O. Rocha in "The Activation of Dioxygen and Homogeneous Catalytic Oxidation", p. 45, D. H. R. Barton et al. (Eds.), Plenum Press, New York (1993); (b,c) International Patent Applications 92/18449, 94/ 14740, Solvay Interox.

(C) 2000 IUPAC, Pure and Applied Chemistry 72, 1289-1304 
78. Recent review W. Adam, M. Lazarus, C. R. Saha-Möller, O. Weichold, U. Hoch, D. Häring, P. Schreier. Adv. Biochem. Eng./Biotechn. 63, 73-108 (1999).

79. M. Rüsch gen Klaas and S. Warwel. J. Mol. Cat. A: Chem. 117, 311-9 (1997).

80. M. Rüsch gen Klaas and S. Warwel. Recent Devevlopments in the Synthesis of Fatty Acid Derivatives, G. Knothe and J. T. P Derksen (Eds.), ch. 10, pp. 157-81, AOCS Press, Illinois (1999).

81. M. Rüsch gen Klaas and S Warwel. Org. Letter, 1(7), 1025-6 (1999); (b) idem, German Patent DE 19738442 (S. Warwel and M. Rüsch gen Klaas).

82. (a) G. B. Shul'pin, G. Süss-Fink, J. R. Lindsay-Smith. Tetrahedron 55, 5345-8 (1999); J. R. Lindsay-Smith and G. B. Shul'pin, Tetrahedron Lett., 39, 4909-12 (1998).

83. (a) J. H .Espenson, Z. Zhu, T. H. Zauche. J. Org. Chem. 64, 1191-6 (1999); (b) T. H. Zauche and J. H. Espenson. Inorg. Chem. 37(26), 6827-31 (1998).

84. (a) M. E. Davis. ACS Symp. Ser. 561, 27-37 (1994); (b) J. L. Casci, Stud Surf Sci Catal 1994, 85, 329-56; refs 70 and 75

85. (a) Ge faujasite: V. I. Parvulescu, D Dumitriu, G. Poncelet. J. Mol. Cat. A: Chem. 140(1), 91-105 (1999); (b) Sn ZSM-12: N. K. Mal, A. Bhaumik, R. Kumar, A. V. Ramaswamy. Catal. Lett. 33, 387-94 (1995); (c) Ti mordenite: A. A. Belhekar, T.K.Das, K. Chaudhuri, S. G. Hegde, A. J. Chandwekar. Stud. Surf. Sci. Catal. 113, 195-200 (1998); (d) Ti APO: D. B. Akolekar and R. Ryoo. J. Chem. Soc. Faraday Trans. 92(22), 4617-21 (1996); (e) V ZSM-48: A. Tuel and Y. Ben Taârit. Zeolites 14(1), 18-24 (1994); (f) Zr mesoporous $\mathrm{SiO}_{2}$ : S. Gontier and A. Tuel. Appl. Cat. A: Gen. 143(1), 125-35 (1996).

86. K. J. Balkus and A. G. Gabrielov. J. Inclus. Phenom. Molec. Recogn. Chem. 21, 159-84 (1995).

87. (a,b) International Patent Applications WO 99/28035 A1, WO 99/28029 A1 (Solvay, M. Strebelle, J.-P. Catinat).

88. (a) K. Sato, M Aoki, M. Ogawa, T Hashimoto, R. Noyori. J. Org. Chem. 61(23), 8310-1 (1996); (b) K. Sato, M. Aoki, M. Ogawa, T. Hashimoto, D. Panyella, R. Noyori. Bull. Chem. Soc. Jpn. 70, 905-15 (1997). 